\title{
Tuntutan Kinerja dalam Keterancaman Kerja: Dilema Karir Penyuluh Agama Non Pegawai Negeri Sipil
}

\author{
Sifatul Aliyah \\ Bimbingan dan Konseling Islam \\ UIN Sunan Kalijaga Yogyakarta \\ Bayu Mitra A. Kusuma \\ Manajemen Dakwah \\ UIN Sunan Kalijaga Yogyakarta
}

Korespodensi dengan Penulis:

Bayu Mitra A. Kusuma, Telp: 082298126489

E-mail: bayu.kusuma@uin-suka.ac.id

\section{Keywords: \\ Performance \\ Demands, Non- \\ PNS Religious \\ Counselor, Job \\ Vulnerability}

Kata kunci:

Permintaan

Kinerja, Konselor

Agama Non-

PNS, Kerentanan

Kerja

\begin{abstract}
Religious counselors are the spearhead profession in the spread of religion while representing the government in delivering religious and development programs in the national and local level. They are not only consist of civil servants (PNS) employees, but also non-civil servants (non-PNS) employees. For those who already have PNS status, their careers are generally more certain and in a safe position. On the contrary, for those with non-PNS status, they are in a dilemma. On the one hand, their existence really has important meaning in the midst of the rise of various religious issues. But on the other hand, they are in a stagnant career condition, there is no career certainty and lack of attention compared to the PNS. Therefore, basically it is necessary to empower non-PNS religious counselor. The research result shows that the government through the Ministry of Religious Affairs actively has attempted to empower non-PNS religious counselor with the Islamic Information Information Management System and the E-PAI application. In addition the government has made efforts such as training and coaching, examining performance reports, making clear guidelines or regulations, and upgrading the salary up to 100 percent. The research method used in this study is descriptive qualitative type and emphasizes on the study of literature.
\end{abstract}

\begin{abstract}
Abstrak
Konselor agama adalah profesi ujung tombak dalam penyebaran agama sembari mewakili pemerintah dalam menyampaikan program agama dan pembangunan di tingkat nasional dan lokal. Mereka tidak hanya terdiri dari pegawai negeri sipil (PNS), tetapi juga karyawan bukan pegawai negeri sipil (non-PNS). Bagi mereka yang sudah memiliki status PNS, karier mereka umumnya lebih pasti dan dalam posisi aman.
\end{abstract}


Sebaliknya, bagi mereka yang berstatus non-PNS, mereka berada dalam dilema. Di satu sisi, keberadaan mereka benar-benar memiliki makna penting di tengah maraknya berbagai persoalan agama. Namun di sisi lain, mereka berada dalam kondisi karir yang stagnan, tidak ada kepastian karir dan kurangnya perhatian dibandingkan dengan PNS. Karena itu, pada dasarnya perlu memberdayakan konselor agama nonPNS. Hasil penelitian menunjukkan bahwa pemerintah melalui Kementerian Agama secara aktif telah berusaha memberdayakan konselor agama non-PNS dengan Sistem Manajemen Informasi Informasi Islam dan aplikasi E-PAI. Selain itu pemerintah telah melakukan upaya seperti pelatihan dan pembinaan, memeriksa laporan kinerja, membuat pedoman atau peraturan yang jelas, dan meningkatkan gaji hingga 100 persen. Metode penelitian yang digunakan dalam penelitian ini adalah tipe kualitatif deskriptif dan menekankan pada studi literatur.

\section{PENDAHULUAN}

Manusia diciptakan satu frekwensi dengan berbagai problematika dan kebutuhan hidupnya. Adanya berbagai problematika dan kebutuhan tersebut kemudian secara stimulan menuntut manusia untuk memenuhinya dengan cara bekerja sesuai dengan passion dan kemampuannya. Sebagian memilih untuk menjadi freelancer atau berwirausaha dengan alasan ingin bekerja secara lebih bebas tanpa harus mematuhi aturan rigid ala kantoran. Hal ini banyak terjadi pada generasi milenial. ${ }^{1}$ Namun tak sedikit pula yang memlih untuk menjadi karyawan di lembaga formal yang penuh dengan tata tertib baik itu di sektor swasta maupun pemerintah. Pada umumnya mereka yang terjun di sektor pemerintahan mengejar status Pegawai Negeri Sipil (PNS). Alasannya karena PNS memberikan kepastian karir berjenjang dan penggajian rutin hingga ajal menjemput. Setiap tahun masyarakat berbondong-bondong mendaftarkan diri dan berebut kesempatan secara sporadis dalam tes Calon PNS yang diharapkan selain untuk mendapatkan penghasilan juga merengkuh status sosial di tengah masyarakat.

Meskipun faktanya tak setiap individu memiliki kesempatan untuk diterima sebagai PNS, namun kondisi tersebut tak menyurutkan keinginan masyarakat untuk menjadi abdi negara melalui jalur alternatif lainnya yang juga disediakan pemerintah, yaitu jalur pegawai non-PNS. Sebenarnya ranah kinerja mereka berada di antara informal maupun formal dengan porsi tanggung jawab yang cukup besar pula. Maka tidaklah mengherankan apabila mereka seringkali mendapat sebutan the real civil service ketimbang PNS yang selalu berdedikasi secara penuh

\footnotetext{
${ }^{1}$ Mustofa, “Pekerja Lepas (Freelancer) dalam Dunia Bisnis", Jurnal Mozaik, Vol. X No. 1, 2018, hlm. 20.
} 
dalam mengemban amanah tugas. ${ }^{2}$ Di lingkungan Kementerian Agama, salah satu posisi yang menawarkan status pegawai non-PNS adalah penyuluh agama. Penyuluh agama merupakan profesi yang menjadi ujung tombak dalam syiar agama dan juga mewakili pemerintah dalam menyampaikan program keagamaan dan progres pembangunan secara nasional. Hal tersebut sesuai dengan Keputuan Bersama Menteri Agama RI dan Kepala Badan Kepegawaian Negara nomor 574 tahun 1999 dan nomor 178 tahun 1999 tentang jabatan fungsional penyuluh agama dan angka kreditnya yang secara detail menyebutkan bahwa penyuluh agama adalah PNS yang diberi tugas, tanggung jawab, wewenang untuk melakukan kegiatan bimbingan dan penyuluhan agama pembangunan melalui bahasa agama.

Secara umum terdapat beberapa fungsi penyuluh agama, diantaranya: Pertama, fungsi informatif dan edukatif, dimana penyuluh agama memposisikan dirinya sebagai juru dakwah untuk menyampaikan penerangan agama dan mendidik masyarakat sebaik-baiknya sesuai ajaran agama. Kedua, fungsi konsultatif, penyuluh agama menyediakan dirinya untuk memikirkan dan memecahkan persoalan-persoalan yang dihadapi masyarakat. Ketiga, fungsi administratif, penyuluh agama memiliki tugas untuk merencanakan, melaporkan, dan mengevaluasi pelaksanaan penyuluhan dan bimbingan yang telah dilakukan. ${ }^{3}$

Melihat perannya yang begitu strategis, maka penyuluh agama sangat dibutuhkan di tataran akar rumput. Sayangnya jumlah penyuluh agama berstatus PNS dirasa masih kurang. Mengingat pemerintah sempat memberlakukan moratorium CPNS selama beberapa tahun, maka kemudian sebagai solusi Kementerian Agama merekrut penyuluh agama berstatus nonPNS. Meskipun memiliki tugas pokok fungsi yang sama dengan penyuluh agama PNS, namun posisi penyuluh agama non-PNS dalam keadaan yang masih dilematis. Di satu sisi secara ideal keberadaan mereka sangat diperlukan di tengah maraknya berbagai persoalan keagamaan masyarakat. Namun di sisi lain, mereka dalam kondisi karir yang stagnan, kurang ada tantangan kerja, dan mendapat lebih sedikit atensi.

Sebagaimana telah dikemukakan sebelumnya bahwa pemerintah pusat sempat memberlakukan moratorium rekrutmen CPNS mulai tahun 2014 hingga 2017, pada masa itu Kementerian Agama banyak merekrut penyuluh agama lewat jalur non-PNS karena selain jumlahnya yang masih kurang, juga banyak yang tidak lagi muda dan nyaris pensiun. Kementerian Agama melakukan perekrutan secara ketat meskipun sebenarnya banyak membutuhkan tenaga penyuluh agama. Namun dibalik selektifnya proses rekrutmen,

${ }^{2}$ Wasisto Raharjo Jati, “Analisa Status, Kedudukan, dan Pekerjaan Pegawai Tidak Tetap dalam UU No. 5/2014 tentang Aparatur Sipil Negara", Jurnal Borneo Administrator, Vol. 11, No. 1, 2015, hlm. 101.

${ }^{3}$ Majelis Ulama Indonesia, Mimbar Ulama Edisi 372, 2015, hlm. 64. 
honorarium yang diberikan kepada penyuluh agama non-PNS hingga tahun 2018 masih sangat minim dan tidak berdasarkan Standar Biaya Masukan (SBM) yang dikeluarkan oleh Kementerian Keuangan. Berangkat dari kondisi tersebut, maka diperlukan adanya pemberdayaan bagi penyuluh agama khususnya non-PNS. Peraturan tertinggi yang menaungi sejauh ini hanyalah Keputusan Menteri Agama (KMA) Nomor 148 Tahun 2014 tentang Penetapan Honoraium bagi Penyuluh Agama non-PNS, sementara regulasi yang mengatur mengenai tugas dan kinerja penyuluh agama hingga saait ini masih dikeluarkan oleh masing-masing Kantor Kementerian Agama di level Kabupaten atau Kota. ${ }^{4}$

Menurut data dari Direktorat Urusan di Lingkungan Kementerian Agama tahun 2014 saja, tercatat ada 118.194 penyuluh agama non-PNS dari berbagai agama, angka ini jauh lebih tinggi daripada jumlah penyuluh agama PNS yakni 4.755 penyuluh. Jika diprosentasekan penyuluh agama PNS berkisar 4\% sedangkan penyuluh agama non PNS 96\%.5 Dengan melihat jumlah penyuluh agama non-PNS yang demikian banyak dan dikomparasikan dengan pendapatan yang belum memadai, memunculkan pertanyaan tentang bagaimana upaya pemerintah khususnya Kementerian Agama dalam memberdayakan penyuluh agama non-PNS guna peningkatan kompetensinya, terutama sebelum dilakukannya evaluasi kinerja.

\section{METODE}

Untuk mengungkap secara jelas bagaimana upaya Kementerian Agama dalam pemberdayaan penyuluh agama non-PNS di tengah tingginya tuntutan kinerja, maka dibutuhkan metode penelitian yang tepat meskipun kajian ini memiliki limitasi pada studi literatur. Penelitian ini menggunakan jenis kualitatif dengan pendekatan analisis deskriptif. Penulis menggunakan penelitian kualitatif deskriptif agar hasil dari penelitian dapat dideskripsikan dan digambarkan dalam kalimat yang sistematis, faktual dan akurat mengenai fakta-fakta dan hubungan antar fenomena. Metode kualitatif adalah prosedur penelitian yang menghasilkan data deskriptif berupa kata-kata atau lisan dari orang dan perilaku yang dapat diamati. 6

Jadi pendekatan ini akan diarahkan pada latar belakang objek penelitian secara keseluruhan. Paradigma kualitatif disebut pendekatan konstruktivis atau naturalistik,

4 M. Agus Noorbani, "Penyelenggaraan Kepenyuluhan Agama Islam Non-PNS di Kota Depok", Penamas: Jurnal Penelitian Keagamaan dan Kemasyarakatan, Vol. 29, No. 1, 2016, hlm. 153.

${ }^{5}$ Kustini, "Mencari Format Ideal Pemberdayaan Penyuluh Agama dalam Peningkatan Pelayanan Keagamaan", (Jakarta: Puslitbang Kehidupan Keagamaan Kemenag, 2014), hlm. xv.

${ }^{6}$ Lexi J. Moleong, "Metode Penelitian Kualitatif", (Bandung: Remaja Rosdakarya, 2000). 
pendekatan interpretatif, atau postpositivist atau perspektif post-modern. ${ }^{7}$ Teknik pengumpulan data dilakukan melalui analisis dokumen atau literatur terkait pemberdayaan dan evaluasi kinerja penyuluh agama non-PNS di Indonesia beserta dinamikanya. Adapun metode analis data yang digunakan dalam tulisan ini adalah metode interaktif Miles dan Huberman yang terdiri dari empat tahap yaitu: pengumpulan data, reduksi data, penajian data dan penarikan kesimpulan. ${ }^{8}$

\section{HASIL DAN PEMBAHASAN}

\section{Urgensi Penyuluh Agama dan Kinerjanya}

Secara general dapat dimaknai bahwa penyuluhan merupakan sebuah aktivitas pemberian nasihat dengan atau berupa anjuran-anjuran dan sasaran-sasaran dalam bentuk pembicaraan yang komunikatif antara penyuluh dan klien. Penyuluh agama adalah petugas yang pekerjaan sehari-hari memberikan penyuluhan kepada masyarakat perihal keagamaan. Berdasarkan Keputusan Menteri Agama Nomor 79 Tahun 1985, bahwa keberadaan penyuluh agama dalam berbagai jenjang mempunyai peranan yang penting dalam kehidupan beragama, bermasyarakat, dan bernegara, antara lain: sebagai pembimbing masyarakat, sebagai panutan, dan sebagai penyambung tugas pemerintah. ${ }^{9}$

Dari ketiga peran tersebut dapat dikatakan bahwa penyuluh agama bertindak sebagai pembimbing masyarakat yang diperlukan ketokohannya dalam bidang keagamaan. Karena itu biasanya penyuluh agama diasumsikan memiliki penguasaan ilmu agama yang lebih baik dan mumpuni dibandingkan masyarakatnya awam pada umumnya, dan dapat berfungsi sebagai sumber rujukan dalam keberagamaan harian. Seorang penyuluh agama Islam yang baik memiliki beberapa kriteria: pertama, mampu memberikan arahan atau petunjuk menuju tingkat pemahaman, penghayatan, dan pelaksana ajaran agama Islam yang berkualitas. Oleh karena itu, pada level tersebut diperlukan penyuluh yang memiliki pemahaman dalam aspek-aspek yang komprehensif.

Kedua, mampu menjadi teladan berbagai aspek kehidupan, khususnya dalam keberagaman. Ketika penyuluh agama menyampaikan nilai-nilai Islam kepada masyarakat dalam kehidupan sehari-hari, maka penyluh agama haruslah terlebih dahulu menjadi pelopor atau pelaku pelaksanaan nilai-nilai tersebut. Atau dengan kata lain, penyuluh tidak hanya

\footnotetext{
7 John W. Creswell, “Qualitative Inquiry and Research Design”, (New York: Sage Publications, 1998).

8 Matthew B. Miles dan Michael A. Huberman, "Qualitative Data Analysis: A Source Book of New Methods", (London: Sage Publication, 1998).

${ }^{9}$ Aep Kusnawan, "Urgensi Penyuluhan Agama”, Ilmu Dakwah: Academic Journal for Homiletic Studies, Vol. 5, No. 17, 2014, hlm. 275.
} 
berhenti bermain ada aspek verbal yang bersifat retorika semata, namun juga harus menjadi barometer perilaku yang dapat dicontoh oleh masyarakat. Ketiga, mampu menjadi penyambung tugas pemerintah atau menjadi jembatan kepentingan antara pemerintah dengan masyarakat. Pada level tersebut, seorang penyuluh agama harus mampu menjadi komunikator yang berimbang dari kepentingan kedua pihak, khususnya terkait dengan penyikapan berbagai kebijakan dalam pembangunan agama. Fungsi tersebut dijalankan melalui dua mekanisme yaitu melalui jalur formal ataupun melalui jalur non-formal.

Selain memiliki peran yang strategis, penyuluh agama juga mempunyai tugas yang tak ringan. Pada hakekatnya secara umum tugas yang diemban oleh para penyuluh agama adalah membimbing umat dalam menjalankan ajaran agama dan menyampaikan gagasan-gagasan pembangunan kepada masyarakat dengan menggunakan bahasa agama dan meningkatkan kerukunan hidup beragama. Selain itu tugas pokok penyuluh agama ada dua: pertama, melaksanakan bimbingan agama Islam, yaitu proses pemberian bantuan kepada Individu secaraberkelanjutan dan sistematis yang dilakukan oleh penyuluh agama Islam yang telah mendapatkan pendidikan dan pelatihan khusus. Kedua, melakukan penyuluhan agama Islam, yaitu proses atau upaya melakukan perubahan perilaku dalam beragama melalui penyebaran informasi, komunikasi, motivasi dan edukasi baik secara lisan, tulisan, peragaan maupun pendampingan kepada kelompok binaan. ${ }^{10}$

Dalam menjalani kariernya, penyuluh agama tentu memerlukan adanya pemberdayaan, khususnya penyuluh agama non-PNS. Meskipun harus diakui bahwa memberdayakan penyuluh agama di Indonesia tidak mudah, karena pekerjaan yang ada di penyuluh agama pada dasarnya bisa dilakukan oleh siapapun yang memiliki kemampuan dalam berdakwah. Pemberdayaan itu sendiri merupakan pemberian atau pengalihan sebagian kekuasaan agar secara individu menjadi lebih berdaya. ${ }^{11}$ Dalam hal ini pemberdayaan ditujukan demi peningkatan karir penyuluh agama agar profesi tersebut menjadi lebih berdaya dalam kinerjanya. Kinerja adalah kegiatan memperbandingkan kinerja aktual bawahan dengan standarstandar yang telah ditetapkan. Penilaian kinerja dapat didefinisikan sebagai prosedur yang meliputi: (1) penetapan standar kerja; (2) penilaian kinerja aktual karyawan dalam hubungan dengan standar-standar yang telah ditetapkan; dan (3) memberi umpan balik kepada karyawan

${ }^{10}$ Muhammad Umar Fauzi, "Strategi Penyuluh Agama Islam dalam Faham Radikalisme di Kabupaten Nganjuk", Jurnal Studi Islam dan Muamalah, Vol. 6, No. 1, 2018, hlm. 28.

${ }^{11}$ Abdul Basit, "Tantangan Profesi Penyuluh Agama Islam dan Pemberdayaannya”, Jurnal Dakwah: Media Dakwah dan Komunikasi, Vol. XV, No. 1, 2014, hlm. 174. 
dengan tujuan memotivasi orang tersebut untuk menghilangkan penurunan kinerja atau terus berkinerja lebih tinggi. ${ }^{12}$

Untuk mencapai kinerja yang optimal tersebut, penyuluh agama juga harus mempunyai kompetensi, diantaranya: (1) kompetensi substantif berkenaan dengan kemampuan penyuluh agama dalam penguasaan terhadap pesan-pesan atau materi yang akan disampaikan kepada objek dakwah; (2) kompetensi metodologis berkenaan dengan kemampuan dalam menyampaikan pesan-pesan dakwah secara efektif dan efisien; (3) kompetensi sosial ditandai dengan adanya kesadaran sosial dan keahlian sosial dalam diri penyuluh agaman dengan digambarkan dalam pribadinya yang pemurah dan bijak terhadap setiap kenyataan yang dihadapinya serta memiliki sikap simpati dan empati; dan (4) kompetensi personal yang lebih menekankan pada kemampuan yang berkenaan dengan moralitas dan kemampuan intelektual. ${ }^{13}$ Jika penyuluh agama non-PNS belum memiliki kompetensi tersebut, maka diperlukan berbagai upaya oleh pemerintah agar kompetensi tersebut dapat dicapai. Yang perlu dicatat, kinerja tersebut perlu dilakukan dengan mengedepankan karakteristik lokal atau indigenous yang dapat dimaknai sebagai sebuah ikhtiar dalam menemukan atau mengembangkan konsep kinerja yang kontekstual atau pengelolaan organisasi berbasis lokalitas. ${ }^{14}$ Dalam hal ini yaitu disesuaikan dengan kebutuhan Kementerian Agama.

\section{Profil Penyuluh Agama Kementerian Agama}

Di bagian sebelumnya secara tegas telah disebutkan bahwa penyuluh agama merupakan para juru dakwah yang diberi hak secara penuh oleh pemerintah melalui Kementerian Agama untuk melakukan kegiatan bimbingan atau penyuluhan agama terhadap masalah keimanan di tengah masyarakat. Di era dimana terjadi disrupsi sosial ini, penyuluh agama diharapkan dapat terus berkontribusi dalam mensyiarkan dan mentransfer risalah agama Islam yang damai dan menyejukkan. Penyuluh agama khususnya non-PNS di lapangan dalam berdakwah harus mempunyai sikap sebagai penengah, penyeimbang, tegak lurus, dan toleransi pada berbagai perbedaan atau keragaman. Saat ini jumlah penyuluh agama non-PNS di Indonesia berkisar 41.460 dan tersebar di berbagai provinsi, dengan rincian data sebagai berikut: ${ }^{15}$

${ }_{12}$ Abdul Munir Mulkhan, “Ideologisasi Gerakan Dakwah", (Yogyakarta: SI Press, 2002), hlm. 234.

${ }^{13}$ Abdul Basith, "Filsafat Dakwah", (Jakarta: Diktis Kemenag, 2012), hlm. 165.

${ }^{14}$ Bayu Mitra A. Kusuma dan Ihsan Rahmat, "Indigenous Performance Management: Menelusuri Praktik Kinerja dalam Perspektif Islam dan Lokalitas", dalam Bayu Mitra A. Kusuma dan Ihsan Rahmat (eds.), Mozaik Islam dan Manajemen Kinerja, (Yogyakarta: Samudra Biru dan MD UIN Sunan Kalijaga), hlm. ix.

15 Kementerian Agama, Jumlah Penyuluh Non-PNS Seluruh Indonesia, diakses melalui http:/ / simpenais.kemenag.go.id/nonpns pada 22 Maret 2018. 
Tabel 1. Persebaran Penyuluh Agama Non-PNS

\begin{tabular}{|c|c|c|}
\hline No. & Provinsi & Jumlah \\
\hline 1. & Nangroe Aceh Darussalam & 1.613 \\
\hline 2. & Kepulauan Bangka Belitung & 320 \\
\hline 3. & Sulawesi Barat & 405 \\
\hline 4. & Kalimantan Utara & 160 \\
\hline 5. & Kepulauan Riau & 426 \\
\hline 6. & DKI Jakarta & 780 \\
\hline 7. & Jawa Barat & 5.196 \\
\hline 8. & Jawa Tengah & 4.519 \\
\hline 9. & Daerah Istimewa Yogyakarta & 773 \\
\hline 10. & Jawa Timur & 4.871 \\
\hline 11. & Banten & 1.200 \\
\hline 12. & Bali & 306 \\
\hline 13. & Nusa Tenggara Barat & 849 \\
\hline 14. & Sumatera Utara & 2.453 \\
\hline 15. & Nusa Tenggara Timur & 1.018 \\
\hline 16. & Kalimantan Barat & 1.296 \\
\hline 17. & Kalimantan Tengah & 804 \\
\hline 18. & Kalimantan Selatan & 1.181 \\
\hline 19. & Kalimantan Timur & 990 \\
\hline 20. & Sulawesi Utara & 577 \\
\hline 21. & Sulawesi Tengah & 891 \\
\hline 22. & Sulawesi Selatan & 2.146 \\
\hline 23. & Sulawesi Tenggara & 1.228 \\
\hline 24. & Sumatera Barat & 978 \\
\hline 25. & Gorontalo & 527 \\
\hline 26. & Maluku & 381 \\
\hline 27. & Maluku Utara & 24 \\
\hline 28. & Papua & 387 \\
\hline 29. & Riau & 1.222 \\
\hline 30. & Jambi & 976 \\
\hline 31. & Sumatera Selatan & 1.589 \\
\hline 32. & Bengkulu & 887 \\
\hline \multirow[t]{2}{*}{33.} & Lampung & 487 \\
\hline & Jumlah & 41.460 \\
\hline
\end{tabular}

Jika dibandingkan data tahun 2014 yang dipaparkan di bagian pendahuluan kajian ini, pada tahun 2018 memang terjadi penurunan jumlah penyuluh agama non-PNS secara kuantitas. Namun dengan melihat jumlah kuantitas penyuluh agama non-PNS sebagaimana data terjadi di atas, tentu pemerintah perlu untuk banyak melakukan upaya optimasi agar kinerja mereka dapat terdata dengan baik. Padahal secara keseluruhan evaluasi kinerja terhadap penyuluh agama non- 
PNS biasanya dilaksanakan sekali dalam setahun, namun apabila ternyata sebelum waktunya sudah diperlukan maka evaluasi juga dapat dilakukan secara insidental. Hasil rangkaian evaluasi ini digunakan sebagai dasar untuk mengangkat atau tidak mengangkat kembali penyuluh agama Islam non-PNS yang bersangkutan. Mereka yang tidak diangkat kembali biasanya dipandang tidak memiliki komitmen kepada tugas mereka sebagai penyuluh agama. Seperti yang terjadi di Bali baru-baru ini, jika ditemukan penyuluh agama Islam non-PNS yang dianggap tidak mampu melaksanakan tugasnya dengan baik maka akan dilakukan Pergantian Antar Waktu (PAW) sesuai ketentuan yang berlaku. ${ }^{16}$ Pada poin inilah penulis mengatakan terjadi keterancaman jabatan dalam tuntutan kinerja. Karena itu sekali lagi perlu dipertegas bahwa pemerintah melalui Kementerian Agama berkewajiban untuk meningkatkan standar kompetensi penyuluh agama non-PNS dan menyediakan akses wahana yang mudah untuk menunjukkan prestasi mereka.

\section{Upaya Meningkatkan Kinerja Penyuluh}

Salah satu strateginya adalah Kementerian Agama membuat aplikasi E-PAI sebagai alat monitoring dan pelaporan. Melalui aplikasi ini, para penyuluh agama bisa memasukkan data kegiatan yang dilakukannya secara detail ke aplikasi ini. Selain itu Kementerian Agama juga berinovasi dengan meluncurkan website SIMPENAIS (Sistem Informasi Manajemen Penerangan Agama Islam) yang dikembangkan untuk memudahkan dalam melakukan pendataan sistem penerangan agama Islam yang ada di Indonesia dan data lembaga-lembaga secara online dimana dapat digunakan untuk menjadi salah satu sumber informasi agama. Adanya program berbasis teknologi tersebut akan merekam dengan jelas prestasi-prestasi yang dihasilkan oleh penyuluh agama non-PNS sehingga dapat memacu kinerja yang semakin baik.

Selain dengan program berbasis teknologi informasi, pemerintah juga melakukan upaya dalam memberdayakan penyuluh agama non-PNS guna peningkatan kompetensi dengan mengadakan beberapa kegiatan untuk menunjang tugas dan kinerja mereka. Tugas dan kinerja penyuluh agama non-PNS masih mengacu pada tugas dan kinerja penyuluh agama PNS. Hingga kini belum ada pembedaan pembagian tugas yang tegas antara penyuluh agama PNS dan penyuluh agama non-PNS, hal yang membedakan antara penyuluh agama PNS dan non-PNS sejauh ini hanya status kepegawaian mereka. Adapun upaya-upaya yang dilakukan Kementerian Agama yang dilakukan pada penyuluh agama non-PNS, antara lain: pertama, melalui bentuk pelatihan dan pembinaan. Pelatihan ini terdiri dari beberapa materi yang disusun dan disampaikan dalam upaya memperkaya pengetahuan penyuluh agama baik yang terkait dengan

\footnotetext{
${ }^{16}$ Kanwil Kementerian Agama Bali, Penyuluh Agama Islam Non PNS yang tidak Kompeten akan di PAW, diakses melalui https://bali.kemenag.go.id/berita/jembrana/9193/penyuluh-agama-islam-non-pnsyang-tidak-kompeten-akan-di-paw pada 26 Mei 2019.
} 
tugas dan wewenang maupun upgrade pengetahuan umum. Misalnya materi yang membahas mengenai aqidah (aspek yang berhubungan dengan masalah masalah keimanan dan dasar dasar agama), muamalah (mulai dari hukum pernikahan, transaksi jual beli, hukum pidana, hukum perdata, hukum perundang-undangan, hukum kenegaraan, keuangan, ekonomi, hingga akhlak dan etika), dan syariah (hukum agama yang menetapkan peraturan hidup manusia baik hubungan manusia dengan manusia, manusia dengan alam maupun hubungan manusia dengan Allah). Di samping itu diadakan juga kegiatan pembinaan berkala, misalnya yang dilakukan secara periodik bulanan.

Kedua, pemeriksaan laporan kinerja. Secara teknis laporan kinerja penyuluh agama nonPNS hasrus dilakukan rutin setiap bulan dan diserahkan dalam bentuk laporan tertulis. Pada umumnya, laporan kinerja tersebut dikumpulkan pada saat menjelang pencairan honorarium. Laporan kinerja tersebut selain sebagai bentuk pengawasan terhadap kinerja penyuluh agama non-PNS juga sebagai media pencatatan prestasi karena dalam konten setiap laporan setiap penyuluh agama non-PNS akan berlomba-lomba menunjukkan hasil pencapaiannya. Dengan berbasis laporan tersebut, juga akan terlihat kelemahan dan kelebihan setiap individu. Catatan tentang kelemahan akan menjadi basis dari penyediaan pelatihan berikutnya sedangkan catatan kelebihan akan memudahkan pemerintah mengidentifikasi penyuluh agama non-PNS yang bisa menjadi contoh bagi koleganya. Ke depan Kementerian Agama akan lebih mengadopsi sistem laporan berbasis daring atau online untuk lebih memonitor tugas dan fungsi penyuluh.

Ketiga, menyusun pedoman atau peraturan yang lebih jelas. Hingga saat ini tugas dan kinerja penyuluh agama Islam non-PNS masih mengacu kepada peraturan yang mengatur tugas dan kinerja penyuluh agama Islam PNS atau tergantung pada keputusan dan kebutuhan masingmasing daerah. Oleh karena itu salah satu upaya yang bijak dalam memberdayakan penyuluh agama adalah dengan menyusun pedoman atau peraturan yang berkaitan dengan tugas, arah, dan fungsi dari penyuluh agama non-PNS secara tegas agar persepsi dan orientasi dalam melakukan perubahan terhadap masyarakat menjadi lebih jelas. Pedoman dan peraturan yang diterbitkan oleh Kementerian Agama tersebut nantinya tidak dimaksudkan untuk menyamaratakan kapasitas dan pemahaman di kalangan para penyukuh agama, akan tetapi lebih berfungsi sebagai payung besar yang harus ditaati bersama berkaitan dengan etika dalam berdakwah, arah dan tujuan yang ingin dicapai, serta berbagai strategi dakwah kontemporer yang perlu dikembangkan oleh para penyuluh agama dalam menghadapi situasi masyarakat yang semakin kompleks.

Keempat, kebutuhan penunjang kerja bagi penyuluh agama non-PNS harus terpenuhi sehingga mereka dapat bekerja dengan optimal. Kabar terbaru di tahun 2019 ini cukup 
menggembirakan karena Kementerian Agama telah menaikkan pendapatan penyuluh agama non-PNS sebesar 100 persen. ${ }^{17}$ Kenaikan gaji untuk penyuluh agama sebenarnya sudah disampaikan sejak tahun 2018, namun berhasil direalisasikan satu tahun kemudian. Setelah mendapatkan kenaikan gaji, penyuluh agama non-PNS juga perlu meningkatkan kerjasama antar penyuluh agama untuk mencapai tujuan bersama yang telah disepakati. Dari kerjasama tersebut setiap penyuluh agama non-PNS dapat bertukar pikiran dan berbagai pengalaman. Ke depan aspek perencanaan sumber daya manusia harus benar-benar digunakan pemerintah untuk mengambil keputusan. Perencanaan sumber daya manusia yang matang perlu dilakukan guna memperjelas status dan jenjang karir para penyuluh agama non-PNS untuk terus dikaryakan beserta upaya-upaya lanjutan untuk meningkatkan kapasitas dan kapabilita mereka. Dengan demikian mereka bisa bekerja dengan lebih maksimal tanpa terlalu takut pada kepastian kesinambungan karier mereka di masa depan.

\section{KESIMPULAN}

Penyuluh agama merupakan profesi yang sangat strategis sebagai jembatan antara pemerintah dan masyarakat perihal pembangunan keagamaan. Karena itu pemerintah melalui kementerian agama harus memperhatikan kesejahteraan dan keberlangsungn karir mereka, baik yang berstatus PNS maupun non-PNS. Terutama bagi penyuluh agama non-PNS, mereka memerlukan perhatian lebih agar mereka tidak merasakan keterancaman jabatan di tengah tuntutan kerja. Dalam upaya optimasi kinerja mereka, pemerintah menggunakan media berbasis teknologi informasi untuk mencatat prestasi mereka misalnya via E-PAI dan SIMPENAIS.

Selain itu, pemerintah juga melakukan berbagai upaya dalam memberdayakan penyuluh agama non-PNS guna peningkatan kompetensi dengan mengadakan beberapa kegiatan untuk menunjang tugas dan kinerja mereka antara lain melalui pelatihan dan pembinaan, menyerahkan laporan kinerja, menyusun pedoman atau peraturan yang lebih jelas, dan menaikkan gaji sebesar 100 persen. Upaya-upaya tersebut merupakan usaha untuk memberdayakan penyuluh agama non-PNS berbasis perencanaan sumber daya manusia. Hal ini agar penyuluh agama non-PNS terus dapat dikaryakan dan memiliki jenjang karir yang lebih menjanjikan. Melalui tulisan ini penulis juga berharap Kementerian Agama agar selalu memperhatikan honorarium untuk penyuluh agama non-PNS sesuai dengan kondisi inflasi yang terus berubah dan buatlah regulasi khusus yang memperkuat posisi mereka sehingga mereka dapat bekerja tanpa dihantui keterancaman kehilangan pekerjaan.

17 Republika, 45 Ribu Penyuluh Agama Islam Non-PNS Naik Gaji, diakses melalui https://www.republika.co.id/berita/dunia-islam/islam-nusantara/19/01/14/plbojj384-45-ribupenyuluh-agama-islam-nonpns-naik-gaji pada s26 Mei 2019. 


\section{DAFTAR RUJUKAN}

Basit, Abdul. "Tantangan Profesi Penyuluh Agama Islam dan Pemberdayaannya”, Jurnal Dakwah: Media Dakwah dan Komunikasi, Vol. XV, No. 1, 2014.

Basith, Abdul. Filsafat Dakwah, Jakarta: Diktis Kemenag, 2012.

Creswell, John W. Qualitative Inquiry and Research Design, New York: Sage Publications, 1998.

Fauzi, Muhammad Umar. "Strategi Penyuluh Agama Islam dalam Faham Radikalisme di Kabupaten Nganjuk", Jurnal Studi Islam dan Muamalah, Vol. 6, No. 1, 2018.

Jati, Wasisto Raharjo. “Analisa Status, Kedudukan, dan Pekerjaan Pegawai Tidak Tetap dalam UU No. 5/2014 tentang Aparatur Sipil Negara", Jurnal Borneo Administrator, Vol. 11, No. 1, 2015.

Kanwil Kementerian Agama Bali. "Penyuluh Agama Islam Non PNS yang tidak Kompeten akan di $P A W^{\prime \prime}$, diakses melalui https://bali.kemenag.go.id/berita/jembrana/9193/penyuluhagama-islam-non-pns-yang-tidak-kompeten-akan-di-paw pada 26 Mei 2019.

Kementerian Agama. "Jumlah Penyuluh Non-PNS Seluruh Indonesia", diakses melalui http://simpenais.kemenag.go.id/nonpns pada 22 Maret 2018.

Kusnawan, Aep. "Urgensi Penyuluhan Agama”, Ilmu Dakwah: Academic Journal for Homiletic Studies, Vol. 5, No. 17, 2014.

Kustini, "Mencari Format Ideal Pemberdayaan Penyuluh Agama dalam Peningkatan Pelayanan Keagamaan", Jakarta: Puslitbang Kehidupan Keagamaan Kemenag, 2014.

Kusuma, Bayu Mitra A. dan Rahmat, Ihsan. “Indigenous Performance Management: Menelusuri Praktik Kinerja dalam Perspektif Islam dan Lokalitas", dalam Bayu Mitra A. Kusuma dan Ihsan Rahmat (eds.), Mozaik Islam dan Manajemen Kinerja, Yogyakarta: Samudra Biru dan MD UIN Sunan Kalijaga.

Majelis Ulama Indonesia. “Mimbar Ulama Edisi 372”, 2015.

Miles, Matthew B. dan Huberman, Michael A. "Qualitative Data Analysis: A Source Book of New Methods", London: Sage Publication, 1998.

Moleong, Lexi J. “Metode Penelitian Kualitatif”, Bandung: Remaja Rosdakarya, 2000.

Mulkhan, Abdul Munir. “Ideologisasi Gerakan Dakwah”, Yogyakarta: SI Press, 2002.

Mustofa, “Pekerja Lepas (Freelancer) dalam Dunia Bisnis”, Jurnal Mozaik, Vol. X, No. 1, 2018. 
Noorbani, M. Agus, "Penyelenggaraan Kepenyuluhan Agama Islam Non-PNS di Kota Depok", Penamas: Jurnal Penelitian Keagamaan dan Kemasyarakatan, Vol. 29, No. 1, 2016.

Republika, 45 Ribu Penyuluh Agama Islam Non-PNS Naik Gaji, diakses melalui https://www.republika.co.id/berita/dunia-islam/islam-nusantara/19/01/14/plbojj38445-ribu-penyuluh-agama-islam-nonpns-naik-gaji pada 26 Mei 2019. 